\title{
Pendampingan Pajak UMKM: Masalah dan Solusinya
}

\author{
Amelia Sandra ${ }^{1)}$, Hanif $^{2)}$, Rizka Indri Arfianti ${ }^{3)}$, Prima Apriwenni ${ }^{4)}$ \\ ${ }^{1234)}$ Program Studi Akuntansi, Institut Bisnis dan Informatika Kwik Kian Gie \\ amelia.sandra@kwikkiangie.ac.id \\ hanif.ismail@kwikkiangie.ac.id \\ rizka.indri@kwikkiangie.ac.id \\ prima.apriweni@kwikkiangie.ac.id
}

\begin{abstract}
ABSTRAK
Pelatihan Pengetahuan Pajak Penghasilan bagi UMKM merupakan salah satu langkah meningkatkan kemampuan para pengusaha yang tergabung dalam UPK PPUKMP Pulo Gadung Jakarta Timur . Pelatihan ini diselenggarakan pada tanggal $17-25$ Januari 2019. Instruktur pelatihan adalah para dosen yang memiliki pengetahuan, keahlian, dan pengalaman dalam membina pelajar. Tujuan dari pelatihan ini, khususnya bagi pengusaha adalah untuk meningkatan kemampuan akuntansi sederhana dan administrasi perpajakan seorang pengusaha dan aspek lain yang berhubungan dengan hal tersebut. Proses pelatihan dimulai dari persiapan dengan menganalisis kebutuhan pelatihan, merumuskan tujuan pelatihan, mempersiapkan materi dan melaksanakan pelatihan. Metode pelatihan dilakukan dengan memberikan ceramah, diskusi, tanya jawab, dan penayangan audio visual. Hasil dari pelatihan ini diharapkan dapat meningkatkan pengetahuan teknis bagi pengusaha dalam memahami kewajiban perpajakannya yaitu cara pengisian SPT terutama pajak penghasilan bagi UMKM dan administrasi pajak yang sebaiknya dilakukan.
\end{abstract}

Kata-kata Kunci: Pajak Penghasilan, UMKM, Administrasi Pajak

\begin{abstract}
Training on Income Tax Knowledge for MSMEs is the one step to improve the entrepreneurs' taxation ability, as the members of the UPK PPUKMP Pulo Gadung East Jakarta. This training was held on 17 - 25 January 2019. Training instructors are lecturers who have a knowledge, expertise, and experience in fostering students. The purpose of this training, especially for entrepreneurs is to improve their simple accounting skills and taxation administration and other aspects related to it. The training process begins with a preparation by analyzing training needs, formulating training objectives, preparing material and conducting training. The training is carried out by giving lectures, discussions, question and answer, and audio-visual presentation. The results of this training are expected to increase technical knowledge for entrepreneurs in understanding their tax obligations, namely how to fill SPT, especially income tax for MSMEs and tax administration that should be done.
\end{abstract}

Keywords: Income Tax, MSMEs, Taxation Administration

\section{PENDAHULUAN}

Informasi akuntansi merupakan alat yang digunakan oleh pengguna informasi untuk pengambilan keputusan, terutama oleh pelaku bisnis. Informasi akuntansi didefinisikan sebagai sistem informasi yang dapat mengukur dan mengkomunikasikan informasi keuangan tentang kegiatan ekonomi. Informasi akuntansi sangat diperlukan oleh pihak manajemen perusahaan dalam merumuskan berbagai keputusan dalam memecahkan segala permasalahan yang dihadapi perusahaan. Informasi akuntansi yang dihasilkan dari suatu laporan keuangan berguna dalam rangka menyusun berbagai proyeksi, misalnya proyeksi kebutuhan uang kas di masa yang akan datang. Dengan menyusun proyeksi tersebut secara tidak langsung akan mengurangi ketidakpastian, antara lain mengenai kebutuhan terhadap kas. 
Informasi akuntansi berhubungan dengan data akuntansi atas transaksi-transaksi keuangan dari suatu unit usaha, baik usaha jasa, dagang maupun manufaktur. Supaya informasi akuntansi dapat dimanfaatkan oleh manajer atau pemilik usaha, maka informasi tersebut disusun dalam bentuk-bentuk yang sesuai dengan Standar Akuntansi Keuangan. Arus informasi akuntansi keuangan dari perusahaan kecil sangat bermanfaat untuk mengetahui bagaimana perkembangan usaha perusahaan, bagimana struktur modalnya, berapa keuntungan yang diperoleh perusahaan pada suatu periode tertentu.

Informasi akuntansi yang banyak disiapkan dan digunakan perusahaan kecil dan menengah adalah informasi yang diharuskan menurut undang-undang atau peraturan (statutory). Selain itu, informasi akuntansi yang seharusnya dibutuhkan oleh manajemen perusahaan kecil dan menengah dalam pengggunaan informasi akuntansi sangat terbatas sekali. Banyak kelemahan dalam praktik akuntansi pada perusahaan kecil. Kelemahan tersebut disebabkan oleh beberapa faktor, antara lain pendidikan dan overload standar akuntansi yang dijadikan pedoman dalam penyusunan pelaporan keuangan

Dari uraian tersebut jelas bahwa industri menengah banyak mengalami kesulitan dalam memahami informasi akuntansi dengan baik. Padahal dengan semakin ketatnya persaingan bisnis dalam era globalisasi ekonomi, hanya perusahaan yang memiliki keunggulan kompetitif yang akan mampu memenangkan persaingan. Keunggulan tersebut diantaranya adalah kemampuan dalam mengelola berbagai informasi, sumber daya manusia, alokasi dana, penerapan teknologi, sistem pemasaran dan pelayanan. Sehingga manajemen perusahaan yang profesional merupakan tuntutan yang harus segera dipenuhi untuk dapat melaksanakan kegiatan-kegiatan perusahaan secara baik.

Informasi akuntansi mempunyai peranan penting untuk mencapai keberhasilan usaha, termasuk bagi usaha kecil. Pencatatan akuntansi dapat menjadi dasar yang andal bagi pengambilan keputusan ekonomis dalam pengelolaan usaha kecil, antara lain keputusan pengembangan pasar, penetapan harga dan lain-lain. Penyediaan informasi akuntansi bagi usaha kecil juga diperlukan khususnya untuk akses subsidi pemerintah dan akses tambahan modal bagi usaha kecil dari kreditur (bank). Pemerintah maupun komunitas akuntansi telah menegaskan pentingnya pencatatan dan penyelenggaraan akuntansi bagi usaha kecil.

Sejauh ini masih banyak usaha kecil menengah (UKM) yang belum menyelenggarakan pencatatan atas laporan keuangan usahanya sedikit banyak berdampak pada sulitnya untuk mendapatkan kredit lunak dari lembaga keuangan. Terlepas dari itu semua, perlunya penyusunan laporan keuangan bagi UKM sebenarnya bukan hanya untuk kemudahan memperoleh kredit dari kreditur, tetapi untuk pengendalian aset, kewajiban dan 
modal serta perencanaan pendapatan dan efisiensi biaya-biaya yang terjadi yang pada akhirnya sebagai alat untuk pengambilan keputusan perusahaan.

UMKM telah terbukti berkontribusi terhadap produk domestik bruto Indonesia. Kontribusinya mencapai 58 persen. Di samping itu, UMKM adalah solusi untuk mengurangi pengangguran. Sejumlah 52 juta warga negara Indonesia yang mengadu peruntungan di sektor UMKM. Dalam hal perpajakan, juga terlihat lebih terpanggil untuk berkontribusi meningkatkan penerimaan negara untuk pembangunan. Lebih dari setengah jumlah peserta yang mengikuti Tax Amnesty adalah UMKM OP dan Badan. Singkatnya, UMKM berpotensi untuk perpajakan Indonesia.

Namun, sudah diketahui banyak pihak potensi pajak yang besar di UMKM belum dapat digali maksimal karena masih kurangnya sosialisasi dan kurangnya pemahaman pelaku UMKM tentang perpajakan. Di samping tentu ada pelaku UMKM yang sudah agak paham dengan perpajakan, tetapi masih ragu untuk tertib membayar pajak. Ada kekhawatiran bahwa ketertiban membayar pajak akan menuntut ketertiban dalam administrasi. Hal ini merupakan sesuatu yang ditakuti oelh para pelaku UMKM. Untuk itulah maka perlu secara pelan namun konsisten, dilakukan pendampingan dan pembinaan terhadap UMKM.

Kebutuhan pendampingan UMKM bidang perpajakan mendesak dilakukan karena dalam PP No. 23 diatur bahwa tarif PPh 21, 0,5\% dari omzet hanya berlaku 7 tahun untuk UMKM OP dan 3 tahun untuk UMKM badan. Setelah itu, perlakuan perpajakan UMKM yang memiliki omzet di bawah Rp. 4,8 milyar, adalah sama dengan usahawan lainnya yang memiliki omzet di atas Rp. 4,8.

Artinya, perhitungan PPh 21 UMKM OP atau badan mengikuti UU PPh Pasal 17, yakni dikenakan tarif progresif dari laba kena pajak. Hal ini tentu akan berdampak besar terhadap adiministrasi perpajakan yang harus dipersiapkan oleh UMKM OP maupun badan.

Berdasarkan uraian di atas, maka kegiatan pengabdian kepada masyarakat yang akan dilakukan adalah peningkatan kemampuan akuntansi sederhana dan administrasi perpajakan bagi UMKM di PIK Pulo Gadung. Rumusan masalahnya adalah sebagai berikut: (a) Wajib Pajak UMKM belum mengetahui tata cara pembuatan pembukuan/administrasi yang sederhana sebagai catatan pembukuan usaha; (b) Kurangnya pemahaman terhadap perubahan PP No.46 Tahun 2013 menjadi PP No.23 Tahun 2018 terhadap perpajakan usaha para wajib pajak UMKM.

Guna menjawab permasalahan tersebut maka tim pengajar melakukan kegiatan pengabdian kepada masyarakat dalam bentuk pendampingan dan fasilitator pada upaya peningkatan kemampuan akuntansi sederhana dan administrasi perpajakan bagi UMKM di PIK Pulo Gadung, Jakarta. 


\section{METODE PELAKSANAAN}

Kegiatan ini terdiri atas dua aktivitas utama, yaitu pembekalan dan pendampingan. Pembekalan dilakukan melalui ceramah, diskusi dan tanya jawab; sedangkan pendampingan dilakukan dalam rangka peningkatan kemampuan perhitungan dan pelaporan pajak penghasilan, serta praktek pengisian dan pelaporan SPT.

\section{HASIL DAN PEMBAHASAN}

Beberapa temuan penting dalam kegiatan yang dilakukan di UMKM di PIK Pulo Gadung pada tanggal 17-25 Januari 2019 dapat diidentifikasi sebagai berikut:

Pertama, adanya hambatan dalam pemasaran kepada instansi pemerintah karena sukarnya memenuhi persyaratan administrasi perpajakan. Beberapa UMKM di PIK berpotensi sebagai pemasok kebutuhan instansi pemerintah dalam banyak produk, seperti kerajinan kulit, sablon, pakaian seragam, dan lain sebagainya. Dari segi kualitas dan harga produk, UMKM dapat bersaing untuk menembus pasar pemerintah. Namun, kendala terbesar justru pada pemenuhan persyaratan administrasi perpajakan. Di satu sisi instansi pemerintah disyaratkan oleh aturan bahwa mereka harus mencari supplier yang berstatus Pengusaha Kena Pajak (PKP). Padahal UMKM yang bergerak di PIK kebanyakan bukan PKP. Sesuai dengan aturan perpajakan bahwa perusahaan yang wajib PKP adalah perusahaan yang memiliki peredaran bruto dalam satu tahun lebih dari Rp. 4,8 milyar atau memiliki peredaran bruto lebih dari Rp. 400 juta per bulan. Sementara untuk UMKM PIK Pulo Gadung yang memiliki peredaran bruto kurang dari Rp. 4.8 milyar per tahun atau peredaran bruto kurang dari Rp. 400 juta per bulan, tidak wajib PKP atau menjadi PKP. Ada pilihan bagi UMKM, mendaftarkan diri menjadi PKP atau tidak. Kecenderungan yang terjadi adalah UMKM PIK lebih memilih tidak mendaftarkan diri menjadi PKP.

Kedua, penyebab UMKM PIK tidak PKP adalah habisnya energi pelaku UMKM untuk kegiatan pencarian pesanan yang makin hari semakin sulit. Sebagian besar energi mereka habis untuk mencari pesanan atau mereka fokus pada pemasaran. Mereka semakin merasakan tingkat persaingan semakin ketat. Apalagi saat ini terdapat tantangan yang sangat besar dengan mudahnya produk buatan Cina menembus pasar Indonesia, termasuk menghantam segmentasi pasar UMKM Indonesia. Jadi, UMKM PIK semakin habis waktunya menghadapi dinamika pemasaran tersebut. Dampaknya, administrasi perpajakan justru menjadi urusan yang kurang mendapatkan perhatian. Apalagi untuk mendaftarkan diri menjadi PKP karena menjadi PKP harus diiringi dengan memperkuat system administrasi keuangan dan perpajakan UMKM. Keinginan untuk memperkuat administrasi keuangan dan perpajakan masih sangat rendah karena sebagaimana dijelaskan di poin pertama bahwa pelaku UMKM fokus pada kegiatan pemasaran dan 
produksi. Dampaknya, hampir tidak ada UMKM di Kawasan PIK Pulo Gadung yang menjadi PKP.

Ketiga, dilema UMKM dalam pemasaran dan keharusan menjadi PKP. Pasar potensial UMKM salah satunya adalah instansi pemerintah. Sementara untuk UMKM harus berusaha keras untuk memperoleh pasar di instansi pemerintah. Tetapi setelah pesanan diperoleh dan disepakati, pelaksanaannya terbentur pada keharusan untuk mengikuti peraturan pengadaan di instansi pemerintah. Singkatnya, peraturan mengharuskan instansi pemerintah untuk pengadaan dengan jumlah tertentu harus membayar pajak PPN yang harus dipungut oleh pihak pemasok atau penjual. Di sinilah, terjadi dilema, UMKM sebagai pemasok (penjual) tidak memiliki hak untuk memungut PPN (10\% dari nilai transaksi) karena tidak menjadi PKP. Akibatnya, tidak jarang UMKM bekerja sama dengan perusahaan - yang notabene - adalah pesaingnya, yang telah PKP sehingga memenuhi syarat untuk bertransaksi dengan instansi pemerintah. Jalan ini terpaksa ditempuh oleh UMKM karena: (a) demi mempertahankan operasional perusahaan agar tetap berjalan untuk memenuhi berbagai jenis tagihan, diantaranya sewa, upah tenaga kerja dan overhead cost; (b) untuk menghindari idle capacity yang akan menambah beban usaha; (c) UMKM harus tetap bertahan (survive). Pekerjaan tersebut harus diambil dengan risiko, dianataranya: (a) keuntungan yang diperoleh UMKM mengecil karena berbagi keuntungan dengan perusahaan yang telah memiliki PKP; (b) risiko kehilangan pasar sebab klien dalam hal ini instansi pemerintah - dapat beralih ke perusahaan yang memiliki PKP yang merupakan mitra UMKM. Hal hal yang telah dijelaskan ini tampaknya menjadi hambatan untuk UMKM tertentu, khususnya yang memiliki pasar instansi pemerintah

Keempat, memberikan bimbingan mengisi ID Billing untuk pembayaran SPT masa. UMKM pada kesempatan ini juga diberi bimbingan untuk mengisi ID billing SPT masa. Tahapannya: (a) komputer harus terkoneksi dengan internet; (b) membuka aplikasi sse.pajak.go.id. (c) melakukan klik pilihan "versi 2"; (d) mengisi data sesuai borang yang tersedia, di antaranya nomor NPWP, password, nama wajib pajak, yang memandu secara otomatis pada link yang dimaksud; (e) Memilih jenis setoran 41128 pajak final dan jenis pajak 420 pajak dengan peredaran bruto tertentu; (f) mengisi masa pajak; (g) mengisi jumlah setoran; dan (h) melakukan klik bagian kanan bawah " ID billing".

Hasil kegiatan program adalah meningkatnya pemahaman para pelaku usaha di lingkungan UPK PPUKMP Pulo Gadung, Jakarta tentang PPh bagi UMKM. Proses pelatihan berlangsung baik dengan dukungan dari para nara sumber dari tenaga pengajar (dosen) yang kompeten dan berpengalaman dalam memberikan pelatihan. Materi pelatihan disuguhkan dengan bahasa dan cara penyampaian yang mudah dicerna bagi para peserta, sehingga banyak tanggapan, pertanyaan, dan harapan yang mereka sampaikan. 


\section{KESIMPULAN}

Kegiatan ini akan sangat lebih baik jika dilakukan secara berkesinambungan dengan memberikan materi secara lengkap mengenai tata cara pembuatan pembukuan/administrasi yang sederhana bagi wajib pajak UMKM sebagai catatan pembukuan usahanya, penerapan perubahan PP No. 46 Tahun 2013 menjadi PP No. 23 Tahun 2018 terhadap perpajakan usaha para wajib pajak UMKM dan pengisian e-Billing dan e-Filing. Kehadiran tim pengajar Program Studi Akuntansi melalui program pengabdian kepada masyarakat dalam pembekalan para pebisnis Anggota UPK PPUKMP Pulo Gadung mendapatkan respon positif.

Di masa yang akan datang, disarankan diselenggarakan program pengabdian kepada masyarakat dalam bentuk ceramah pada komunitas bisnis Pengusaha PIK Pulo Gadung dengan tema-tema yang menarik. Di sisi lain program pengabdian kepada masyarakat secara tidak langsung dapat memberikan efek peningkatan branding pada Institut Bisnis dan Informatika Kwik Kian Gie, termasuk untuk program studi - program studi lainnya.

\section{REFERENSI}

Resmi, S. (2017). Perpajakan, Edisi 10. Jakarta: Salemba Empat.

Republik Indonesia (2008). Undang-undang Nomor 20 Tahun 2008 tentang Usaha Mikro, Kecil dan Menengah.

Republik Indonesia. (2013). PP No. 46 Tahun 2013 tentang Pajak Penghasilan Atas Penghasilan dari Usaha yang Diterima atau Diperoleh Wajib Pajak yang Memiliki Peredaran Bruto Tertentu.

Republik Indonesia. (2018). PP No 23 Tahun 2018 tentang Pajak Penghasilan Atas Penghasilan dari Usaha yang Diterima atau Diperoleh Wajib Pajak yang Memiliki Peredaran Bruto Tertentu.

Waluyo. (2017). Perpajakan Indonesia, Buku 1, Edisi 10. Jakarta: Penerbit Salemba Empat.

www. pajak.go.id 
Academics in Action Journal

Volume 1, Number 1, 2019, 1-7

\section{LAMPIRAN}

\section{Foto-foto Kegiatan}
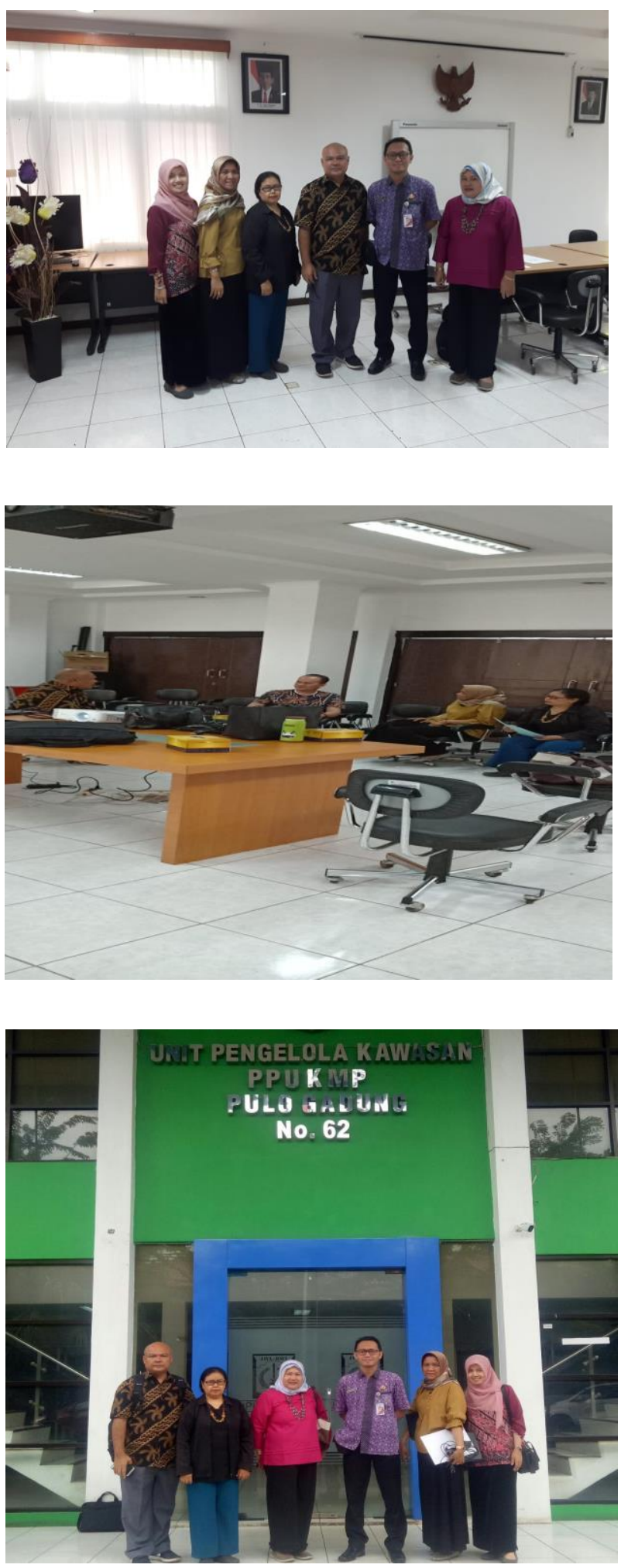